\title{
Seroprevalence and risk assessment of Toxoplasma gondii in Java sparrows (Lonchura oryzivora) in China
}

\author{
Si-Yang Huang ${ }^{1 *}$ (D) Yi-Min Fan ${ }^{1}$, Kai Chen ${ }^{2}$, Qiu-Xia Yao ${ }^{1,2}$ and Bin Yang ${ }^{1}$
}

\begin{abstract}
Background: Toxoplasma gondii, an intracellular zoonotic parasite, infects all mammalian and birds. Understanding the prevalence of Toxoplasma in bird is important for evaluating the transmission of this parasite. No information about the seroprevalence of $T$. gondii in Java sparrows (Lonchura oryzivora) is available.

Results: In this study, from 2014 to 2015, 350 serum samples from Java sparrows were collected in Beijing and Shangqiu, Henan province, and the antibodies against $T$. gondii were evaluated with MAT. The seroprevalence in Java sparrows was $34.29 \%\left(\mathrm{Cl}_{95 \%} 29.31-39.26\right)$. A phenomenon of seropositivity tended to increase with age were observed, but the difference is not significant. The prevalence was significant different in gender and color, which could be risk factors.

Conclusions: This study firstly reported T. gondii seroprevalence in Java sparrows, which extended the host range of $T$. gondii. Java sparrows may pose significant transmission medium, accelerating the spread of $T$. gondii diffusion.
\end{abstract}

Keywords: Toxoplasma gondii, Java sparrows, Seroprevalence, Modified agglutination test (MAT), China

\section{Background}

Toxoplasma gondii is an intracellular zoonotic parasite, which is capable of infecting all mammalian and humans, including birds [1]. It was stated nearly one third of the world population and about $8.0 \%$ people in China were chronically infected by this parasite $[1,2]$. Infection may occur by the ingestion of vegetable or water polluted by oocysts, consumption of undercooked infected meat or by transplancental transmission [3, 4].

People consider birds are important epidemiological indicators because they can reflect the soil contamination with the oocysts of $T$. gondii. At the same time, they are important dissemination medium, which prey on small animals, especially cats. Thus, many studies have been carried out to investigate the prevalence of $T$. gondii among bird species around the world [5-10]. Due

\footnotetext{
* Correspondence: siyang.huang@hotmail.com

${ }^{1}$ Institute of Comparative Medicine, College of Veterinary Medicine,

Yangzhou University, and Jiangsu Co-innovation Center for Prevention and Control of Important Animal Infectious Diseases and Zoonosis, and Jiangsu Key Laboratory of Zoonosis, Yangzhou, Jiangsu Province 225009, People's Republic of China

Full list of author information is available at the end of the article
}

to their colorful feather and elegant posture, some species of birds has been raised as pets in China for a long history, including Java sparrows. Nowadays, many people like to breed Java sparrows as pets, which enhanced their economic value. Although toxoplasmosis was normally asymptomatic chronic infection in birds or chicken, a few of outbreak clinical cases were reported recently [11]. The outbreak can cause great economic loss in bird and chicken production. In captivity, a lots of different colorations were bred, including, silver/opal, cream, fawn/isabel, white, pastel and agate (which is rare within Europe captive specimens) along with the gray Java sparrow. Java sparrows mainly originated from Beijing and Henan provinces in China, where about $70 \%$ of all pet birds were raised each year.

Before toxoplasma were identified (in 1908), two reports descripted toxoplasma-like parasite in Java sparrows in 1900s [12]. There is no exact information about $T$. gondii infection in Java sparrows since that time. The aim of the present study was to survey the seroprevalence of $T$. gondii infection in Java sparrows in China.

(c) The Author(s). 2019 Open Access This article is distributed under the terms of the Creative Commons Attribution 4.0 International License (http://creativecommons.org/licenses/by/4.0/), which permits unrestricted use, distribution, and 


\section{Methods}

\section{The investigated sites}

The examined Java sparrows in present study were collected from two cities, Beijing and Shangqiu (the main production places of pet birds) in China. Beijing is located near to the Yanshan Mountains, the average altitude is around $43.5 \mathrm{~m}$, the annual precipitation is about $626 \mathrm{~mm}$, and the average annual temperature is $12.6{ }^{\circ} \mathrm{C}$. Shangqiu is a city of Henan province, with the altitude ranging from $30 \mathrm{~m}$ to $70 \mathrm{~m}$, the average annual temperature of $14.2^{\circ} \mathrm{C}$.

\section{Collection and preparation of samples}

Samples from 350 birds, including two different color (White and Gray), were collected from markets in Beijing and Shangqiu city during 2014-2015. Blood samples were collected from the wing vein of Java sparrows and incubated at $37 \mathrm{C}$ for $1 \mathrm{~h}$, kept at $4 \mathrm{C}$ for $8 \mathrm{~h}$, and then centrifuged at $3500 \mathrm{~g}$ for $10 \mathrm{~min}$ to separate the sera. The separated sera were stored at $-20 \mathrm{C}$ for further study. Information about species, age, geographic origin, and gender were recoded from the document supplied by local veterinary practitioners.

\section{Serological examination}

Antibodies to $T$. gondii were determined in Java sparrows by the modified agglutination test (MAT) as described previously [13]. Briefly, sera were added to the " $U$ " bottom of 96-well microtiter plates, and diluted 2-fold starting from 1:20 to 1:320. Serum samples were diluted with serum diluting buffer $(0.01 \mathrm{M}$ PBS, $\mathrm{pH}=$ 7.2), and evaluated for anti-Toxoplasma IgG antibodies. The antigens were diluted with antigen diluting buffer, containing $1 \%$ bovine serum albumin (BSA), 2-mercaptoethanol and Evans blue dye solution. Birds sera with MAT titers of 1:20 or higher were considered positive for $T$. gondii infection based on a previous study, positive and negative sera of house sparrows were included as positive and negative controls, respectively, and the doubtful results were re-tested immediately $[6,14]$.

\section{Statistical analysis}

A Chi-square test by SAS were used to analyze the differences in the prevalence of $T$. gondii infection Java sparrows among different variables such as region, color, gender and age, were analyzed using (Statistical Analysis System, Version 8.0). It was considered statistically difference when $P<0.05$. The variables associated to the risk of infection were analyzed in the binary Logit model as independent variables by forward stepwise regression analysis to test the seroprevalence in the multivariable regression analysis. The effects could be included in the model when $P<0.05$.

\section{Results}

A total of $120\left(34.29 \%, \mathrm{CI}_{95 \%} 29.31-39.26\right)$ out of the 350 Java sparrow serum samples were positive for $T$. gondii antibodies analyzed by MAT, with antibody titers of 1:20 in $29,1: 40$ in $44,1: 80$ in $33,1: 160$ in 8 , and 1:320 in 6 samples. There was no statistically difference in the seroprevalence of $T$. gondii between Beijing (38.04\%, $\left.\mathrm{CI}_{95 \%} 30.58-45.49\right)$ and Shangqiu (31.02\%, $\mathrm{CI}_{95 \%} 24.38-$ $37.65, P=0.16)$. The seroprevalence in different age groups ranged from $26.09 \% \quad\left(\mathrm{CI}_{95 \%} 17.11-35.06\right)$ to $45.71 \%\left(\mathrm{CI}_{95 \%} 36.19-55.24\right)$ (Table 1$)$, the seroprevalence increased with age, supporting that seropositivity is related to exposure to $T$. gondii, but the difference was not statistically significant $(P=0.09)$. There was a statistically different between female (54.63\%, $\left.\mathrm{CI}_{95 \%} 85.61-98.76\right)$ and male $\left(25.21 \%, \mathrm{CI}_{95 \%} 16.58-26.08\right)(P<0.01)$. From the results we found that Gray Java sparrow had a higher seropositivity $\left(47.20 \%, \mathrm{CI}_{95 \%} 38.45-55.95\right)$ comparing to white Java sparrow $\left(27.11 \%, \mathrm{CI}_{95 \%} 9.27-18.28\right)$, and the prevalence was significant different $(P<0.05)$. According to the multivariable regression analysis, colors and gender could be risk factors (Table 1).

\section{Discussion}

Due to the special transmission of birds in $T$. gondii, the epidemic of $T$. gondii infection has been studied more and more in recently. This study, for the first time, reported seroprevalence of $T$. gondii in Java sparrows in the world. Although there were two reports descripted toxoplasma-like parasite in Java sparrows in 1900s [12], no further study was reported since that time. Here, our study confirmed that this species of bird is an intermediate host for $T$. gondii using MAT for detection of anti- $T$. gondii antibodies. MAT was developed by professor Dubey in 1987, based on detection of IgG antibodies [13], which has been extensively used for seroprevalence studies in the recent years [6, 15-18].

In this study, the prevalence of $T$. gondii in Java sparrows was $34.29 \%$, which was higher than that in other pet birds, such as in Carduelis spinus (11.65\%), in Alauda gulgula (11.39\%) and in Cocothraustes migratorlus (5.26\%) [6], in pigeons (11.86\%) [19]. These examine method used in above studies was the same with our study, so the seroprevalence differences were not due to the detection method. Thus, various species and sample collected regions may contribute to the differences.

Beijing and Shangqiu were selected for screening $T$. gondii prevalence because they were the main supply areas of the pet birds. In the present study, the seroprevalence of $T$. gondii in Java sparrows is $38.04 \%$ in Beijing and $31.02 \%$ in Shangqiu. The different geographical conditions, especially climates and environment of the two regions may lead to the difference. Although the seroprevalence in Beijing was higher than in Shangqiu, 
Table 1 Toxoplasma gondii prevalence in Java sparrows from Beijing and Shangqiu, China

\begin{tabular}{|c|c|c|c|c|c|}
\hline Factor & Category & No. positive & No. tested & Prevalence (\%) $\left(\mathrm{Cl}_{95 \%}\right)$ & $P$ value \\
\hline \multirow[t]{2}{*}{ Region } & Beijing & 62 & 163 & 38.04 (30.58-45.49) & 0.16 \\
\hline & Shangqiu & 58 & 187 & $31.02(24.38-37.65)$ & \\
\hline \multirow[t]{2}{*}{ color } & White Java sparrow & 61 & 225 & $27.11(9.27-18.28)$ & $<0.05$ \\
\hline & Gray Java sparrow & 59 & 125 & $47.20(38.45-55.95)$ & \\
\hline \multirow[t]{2}{*}{ gender } & female & 59 & 108 & $54.63(85.61-98.76)$ & $<0.01$ \\
\hline & male & 61 & 242 & $25.21(16.58-26.08)$ & \\
\hline \multirow[t]{3}{*}{ Age } & $3 \sim 5$ month & 24 & 92 & $26.09(17.11-35.06)$ & 0.09 \\
\hline & $6 \sim 8$ month & 48 & 153 & $31.37(24.02-38.71)$ & \\
\hline & $>8$ month & 48 & 105 & 45.71 (36.19-55.24) & \\
\hline Total & & 120 & 350 & $34.29(29.31-39.26)$ & \\
\hline
\end{tabular}

the difference was not statistically significant $(P>0.05)$. Recently, a study reported that $T$. gondii prevalence of pet parrots in Beijing is $8.36 \%$, which is much lower comparing to our result in the same area [20]. The difference might due to the different species of bird, probably, the Java sparrows is more sensitive to $T$. gondii than parrots, or other reasons (food and environment of farm) caused this difference.

In the present study, comparing to White Java sparrow, the seroprevalence of Gray Java sparrow (47.20\%) was quite high, and the different was significant $(P<$ $0.05)$. This difference probably resulted from the different color of Java sparrows, the Gray Java sparrows may be easy infected by $T$. gondii comparing to the White Java sparrows. But the detail reasons need to be further study. For the different gender, the positive rate in female was $54.63 \%$, which is more than two times higher than the rate in male $(25.21 \%)$, and the different was statistically significant $(P<0.01)$. The similar phenomenon was also observed in mice, the female mice were found to be more susceptible to acute infection [21].. So, the female Java sparrows are higher at risk of acquiring $T$. gondii infection compared to male.

Felids are essential in the life cycle of $T$. gondii, In 2013-2014, a seroprevalence and genetic characterization study was reported that $50 \%$ of cats collected from Central China (Henan, 257, Beijing, 61) were positive for T. gondii infection [22]. Our samples were also collected from these two area, the high seroprevalence of cats may cause related to the high prevalence of Java sparrows because cats play an important role in the transmission of $T$. gondii. For Java sparrows, most of the infection was happened at the early breed time. At this time, birds were usually bred in semi-free range systems, hundreds of birds were kept in a big bird house. Birds got infected by the food or water which polluted by the oocyst delivered along the cat feces. Before or after the birds were sold to the individual host as pets, the dead bodies were normally treated improperly, most of them were through to rubbish bin directly, and then eat by stray cats, completing the transmission cycle. Birds could transmit the parasite in a long distance, and this transmission route accelerated the spread of $T$. gondii diffusion. Although $T$. gondii is prevalence in stray dogs [23], the transmission effectiveness is lower comparing to cats. The population and the prevalence of toxoplasmosis in cats may affect transmission of the disease to birds. The seroprevalence of $T$. gondii in birds in different regions also may reveal the transmission of the disease in these regions. In this study, there was no significant difference between the two geographic areas surveyed. This could have resulted from the same prevalence of stray cats in these two places. Birds produced in Beijing and Henan were traded throughout China [20], which may serve as a source for T. gondii transmission. Therefore, the results of the present study provided basic knowledge to control the $T$. gondii transmission through bird trade route. PCR method should be included to confirm the infection as our previous reports $[6,14]$, while it is a pity that tissue samples of Java sparrows were not available in this study, the other detecting methods and Isolation of the parasite from infected bird were not performed.

\section{Conclusions}

The results of the present study revealed an overall $T$. gondii seroprevalence of $34.29 \%$ in Java sparrows in China, which may pose significant transmission medium, accelerating the spread of $T$. gondii diffusion. To our knowledge, our study is the first report of $T$. gondii prevalence in Java sparrows, which also extends the host range of $T$. gondii.

\section{Abbreviations}

BSA: Bovine serum albumin; ELISA: Enzyme-linked immunosorbent assay; IFA: Indirect immunofluorescence assay; MAT: modified agglutination test; PBS: phosphate buffered saline

Acknowledgements

Not applicable. 


\section{Funding}

This work was supported by the State Key Laboratory of Veterinary Etiological Biology, Lanzhou Veterinary Research Institute, CAAS (SKLVEB2018KFKT010), the Priority Academic Program Development of Jiangsu Higher Education Institutions (Veterinary Medicine), and the Agricultural Science and Technology Innovation Program (ASTIP) (Grant No. CAAS-ASTIP-2016-LVRI-03)

\section{Availability of data and materials}

The datasets used and analyzed during the current study are available from the corresponding author on reasonable request.

\section{Authors' contributions}

SYH, YMF conceived and designed the study. QXY, KC collected the samples. YMF, BY performed the laboratory analyses. SYH analyzed the data. All authors critically appraised and interpreted the results. SYH drafted the first version of the manuscript. All authors provided feedback on the manuscript, and read and approved the final version.

\section{Ethics approval and consent to participate}

This study was approved by the Animal Ethics Committee of Lanzhou Veterinary Research Institute, Chinese Academy of Agricultural Sciences. All Java sparrows were handled in accordance with good animal practices required by the Animal Ethics Procedures and Guidelines of the People's Republic of China.

\section{Consent for publication}

Not applicable.

\section{Competing interests}

All authors declare that they have no competing interests.

\section{Publisher's Note}

Springer Nature remains neutral with regard to jurisdictional claims in published maps and institutional affiliations.

\section{Author details}

${ }^{1}$ Institute of Comparative Medicine, College of Veterinary Medicine, Yangzhou University, and Jiangsu Co-innovation Center for Prevention and Control of Important Animal Infectious Diseases and Zoonosis, and Jiangsu Key Laboratory of Zoonosis, Yangzhou, Jiangsu Province 225009, People's Republic of China. ${ }^{2}$ State Key Laboratory of Veterinary Etiological Biology, Key Laboratory of Veterinary Parasitology of Gansu Province, Lanzhou Veterinary Research Institute, Chinese Academy of Agricultural Sciences, Lanzhou, Gansu Province 730046, People's Republic of China.

Received: 7 December 2018 Accepted: 29 April 2019

Published online: 06 May 2019

References

1. Dubey JP. Toxoplasmosis of animals and humans, vol. 313. Boca Raton: CRC Press; 2010.

2. Zhou P, Chen Z, Li HL, Zheng H, He S, Lin RQ, et al. Toxoplasma gondii infection in humans in China. Parasit Vectors. 2011:4:165.

3. Dubey JP, Jones JL. Toxoplasma gondii infection in humans and animals in the United States. Int J Parasitol. 2008:38(11):1257-78.

4. Al-Kappany YM, Abbas IE, Devleesschauwer B, Dorny P, Jennes M, Cox E. Seroprevalence of anti-Toxoplasma gondii antibodies in Egyptian sheep and goats. BMC Vet Res. 2018;14(1):120.

5. Cabezon O, Garcia-Bocanegra I, Molina-Lopez R, Marco I, Blanco JM, Hofle U, et al. Seropositivity and risk factors associated with Toxoplasma gondii infection in wild birds from Spain. PLoS One. 2011:6(12):e29549.

6. Cong W, Meng QF, Song HQ, Zhou DH, Huang SY, Qian AD, et al. Seroprevalence and genetic characterization of toxoplasma gondii in three species of pet birds in China. Parasit Vectors. 2014:7:152.

7. Salant H, Hamburger J, King R, Baneth G. Toxoplasma gondii prevalence in Israeli crows and griffon vultures. Vet Parasitol. 2013;191(1-2):23-8.

8. Feng $Y, L u Y$, Wang $Y$, Zhang L, Yang Y. Toxoplasma gondii and Neospora caninum in farm-reared ostriches (Struthio camelus) in China. BMC Vet Res. 2017:13(1):301
9. Dubey JP, Felix TA, Kwok OC. Serological and parasitological prevalence of toxoplasma gondii in wild birds from Colorado. J Parasitol. 2010;96(5):937-9.

10. Ferreira FC Jr, Donatti RV, Marques MV, Ecco R, Preis IS, Shivaprasad HL, et al. Fatal toxoplasmosis in a vinaceous Amazon parrot (Amazona vinacea). Avian Dis. 2012;56(4):774-7.

11. Vielmo A, Pena HFJ, Panziera W, Bianchi RM, De Lorenzo C, Oliveira S, et al. Outbreak of toxoplasmosis in a flock of domestic chickens (Gallus gallus domesticus) and Guinea fowl (Numida meleagris). Parasitol Res. 2019;118(3): 991-7.

12. Tenter AM, Heckeroth AR, Weiss LM. Toxoplasma gondii: from animals to humans. Int J Parasitol. 2000:30(12-13):1217-58.

13. Dubey JP, Desmonts G. Serological responses of equids fed Toxoplasma gondii oocysts. Equine Vet J. 1987;19(4):337-9.

14. Cong W, Huang SY, Zhou DH, Zhang XX, Zhang NZ, Zhao Q, et al. Prevalence and genetic characterization of toxoplasma gondii in house sparrows (Passer domesticus) in Lanzhou, China. Korean J Parasitol. 2013; 51(3):363-7.

15. Dubey JP, Lappin MR, Kwok OC, Mofya S, Chikweto A, Baffa A, et al. Seroprevalence of Toxoplasma gondii and concurrent Bartonella spp., feline immunodeficiency virus, and feline leukemia virus infections in cats from Grenada, West Indies. J Parasitol. 2009;95(5):1129-33.

16. Yuan ZG, Luo SJ, Dubey JP, Zhou DH, Zhu YP, He Y, et al. Serological evidence of Toxoplasma gondii infection in five species of bats in China. Vector Borne Zoonotic Dis. 2013:13(6):422-4.

17. Gennari SM, Niemeyer C, Soares HS, Musso CM, Siqueira GC, Catao-Dias JL, et al. Seroprevalence of Toxoplasma gondii in seabirds from Abrolhos archipelago, Brazil. Vet Parasitol. 2016;226:50-2.

18. Cabezon O, Cerda-Cuellar M, Morera V, Garcia-Bocanegra I, Gonzalez-Solis J, Napp S, et al. Toxoplasma gondii infection in seagull chicks is related to the consumption of freshwater food resources. PLoS One. 2016;11(3):e0150249.

19. Cong W, Huang SY, Zhou DH, Xu MJ, Wu SM, Yan C, et al. First report of Toxoplasma gondii infection in market-sold adult chickens, ducks and pigeons in Northwest China. Parasit Vectors. 2012:5:110.

20. Zhang XX, Zhang NZ, Tian WP, Zhou DH, Xu YT, Zhu XQ. First report of Toxoplasma gondii seroprevalence in pet parrots in China. Vector Borne Zoonotic Dis. 2014;14(6):394-8

21. Roberts CW, Cruickshank SM, Alexander J. Sex-determined resistance to Toxoplasma gondii is associated with temporal differences in cytokine production. Infect Immun. 1995:63(7):2549-55.

22. Yang $Y$, Ying $Y$, Verma SK, Cassinelli AB, Kwok OC, Liang $H$, et al. Isolation and genetic characterization of viable Toxoplasma gondii from tissues and feces of cats from the central region of China. Vet Parasitol. 2015;211(3-4): 283-8.

23. Migliore S, La Marca S, Stabile C. Di Marco Lo Presti V, Vitale M. a rare case of acute toxoplasmosis in a stray dog due to infection of $T$. gondii clonal type I: public health concern in urban settings with stray animals? BMC Vet Res. 2017;13(1):249.

Ready to submit your research? Choose BMC and benefit from:

- fast, convenient online submission

- thorough peer review by experienced researchers in your field

- rapid publication on acceptance

- support for research data, including large and complex data types

- gold Open Access which fosters wider collaboration and increased citations

- maximum visibility for your research: over $100 \mathrm{M}$ website views per year

At BMC, research is always in progress.

Learn more biomedcentral.com/submissions 